\title{
Seen by a Seer
}

by J. Boswell Belcher, Dilke, Sask.

There always seems to be something interesting or new to be seen. In the case of things that are new, being able to enlist the services of a "watcher" is quite a help in finding out what you have "seen."

Some time after seven in the evening on May 25, 1959 as I was coming home to supper on the tractor across a native prairie pasture I noticed a dark bird about the size of a cowbird with light-coloured wing patches fly around the edge of and into the clump of willows by a slough near the trail. This struck me as something unfamiliar so I stopped to investigate. The bird obliged by letting me get within about 15 feet of it as it perched in plain view on a lower branch of the willows and it stayed there until I had seen all I could see without making it fly. Then I went closer in order to make it move a little to get a different view of it before going on my way home. I reported to the watcher that I had seen a medium-plump, slatecoloured bird, about the size of a cowbird, with plain grey breast, light-coloured wing patches, roundshaped head with small dark bill and dark eyes, and a medium-long tail with light-coloured edges which. were noticeable in $\mathrm{flight}$. $\mathrm{The}$ watcher immediately went into a huddle with her bird books and re- collections of unfamiliar birds, and after asking numerous questions, came up with the suggestion - a Townsend's Solitaire.

Next day a neighbour, Mrs. Mortin, phoned to say that she and her 12-year-old son had been "seeing" a bird that day, of which she gave a description almost identical to mine. My sister, the "watcher", was able to say quite confidently: "You've seen a Townsend's Solitaire, very unusual for here as they nest in the mountains where I saw, them when at Banff." The Mortins' farm is about one mile straight north of where I had seen the Solitaire the evening before, so it was quite likely the same individual.

Another interesting thing I noticed was the frequent occurrence of Yellow-headed Blackbirds early this summer. I believe I saw more of them this year than in all my life previously. Prior to the big rain late in June they were often around the windbreak, sometimes 15 or 20 at a time. I had never seen more than one or two at one time in this locality before, and then not every year. Other people in the district have also mentioned seeing them in unusual numbers and frequency. I do not recall having seen any since the big rain two weeks ago.

\section{INFLUX OF YELLOW-HEADED} BLACKBIRDS IN NIPAWIN AREA. - My first observation of the Yellow-headed Blackbird in this district occurred June 3, 1932 near Armley. From then until this spring (1959) I saw fewer than 20 birds, nearly all of these since 1945. At Shindel's slough midway between Codette and Pontrilas, I found my first nest of this species, with six eggs, June 12, 1958. On May 9 this year I saw a male at a roadside pond east of Nipawin, and then over the course of the next two weeks Yellow-heads appeared almost everywhere. At a slough 15 miles west of Nipawin I counted 27 males (the males being easiest to count as for the most part they were singing and displaying while sitting on the tops of cattails). Fourteen males were counted at Shindel's slough, eight miles west of Pontrilas, and 41 south and southeast of Nipawin. On May 22, at a large slough six miles southeast of Nipawin, I estimated that 80-100 pairs were present. Sitting quietly atop an old beaver house at the edge of this slough I had a great opportunity to listen to their queer songs and calls, also to watch the butterfly-like flight of the males while displaying. This was actually my first chance to get acquainted with the Yellow-heads. At nearly all sloughs now occupied by the Yellow-head's I notice a definite decrease in the number of Redwinged Blackbirds.-

Maurice G. Street, Nipawin, Sask. 